\title{
ESCOLAS DE SAMBA, BLOCOS E 0 RENASCIMENTO DA CARNAVALIZAÇÃO
}

José Sávio Leopoldi

Tendo por objetivo final explicar a razão do crescimento acelerado do número de blocos que se apresentam no carnaval do Rio de Janeiro, depois de considerar, não sem alguma observação crítica, o pensamento do historiador russo Bakhtin, que contribuiu decisivamente para o estudo das festas populares, o texto discute o desenvolvimento das escolas de samba nas décadas mais recentes. Destaca, então, a crescente formalização do desfile das escolas, que as tem afastado do espírito carnavalesco original sintonizado com as festas bakhtinianas. Tentando recuperar tal espírito, grande parte da população carioca tem-se juntado aos blocos carnavalescos, movimento que aponta indiscutivelmente para o "renascimento da carnavalização". [abstract on page 277]

ESCOLA DE SAMBA, CARNAVAL, BAKHTIN, BLOCOS CARNAVALESCOS. 
Não existem grupos humanos sem suas especificidades em termos de valores, normas, comportamentos, aspectos políticos e sociais, em suma, sem o que se denominou cultura. Como uma enorme construção imaterial, a sociedade se estabelece sobre adequada estrutura que, em termos antropológicos, consiste em uma abstração, um constructo em que se apoiam as molas mestras que fazem a sociedade funcionar de acordo com suas especificidades culturais. Na realidade, portanto, a estrutura social não existe no sentido de que não pode ser observada concretamente. Além de facilitar a compreensão da engrenagem de seus elementos constituintes, a estrutura consiste, em termos práticos, em um modelo de funcionamento idealizado da sociedade, de onde emergem as normas e leis que a organizam. Pode-se, pois, afirmar que as leis constituem a pedra fundamental de qualquer sociedade. Ao contrário da concepção hobbesiana da sociedade original, não pode haver grupamento humano sem leis, sem normas que constranjam a "liberdade total" dos indivíduos. Como destacou Locke para justificar a emergência do contrato social, é impossível a convivência em sociedade, o desenvolvimento de relações pacíficas, sem leis que orientem comportamentos e estabeleçam valores que alcancem todos os indivíduos.

O que se observa, portanto, é que o constrangimento - expresso em termos de normas, leis, princípios e, mesmo, senso comum - é inerente à vida social. O ser humano está, dessa maneira, sempre limitado, envolvido, constrangido por normas que orientam a vivência coletiva. A liberdade ilimitada que, em regra, empolga seus pensamentos não pode tornar-se realidade, a não ser em termos de ilusão, fantasia ou, então, de um comportamento antissocial com elevado preço a ser pago. Essa dicotomia entre opressão legitimada e liberdade é bastante destacada no pensamento de Mikhail Bakhtin ao contrapor vida oficial e vida popular durante a Idade Média em suas manifestações carnavalescas.

Para o historiador e filólogo russo, autor da celebrada obra A cultura popular na Idade Média e no Renascimento: o contexto de François Rabelais, a vida oficial era aquela comandada pelo Estado e pela Igreja em que se destacavam as hierarquias, as separações entre os indivíduos, o respeito às manifestações religiosas, às leis que organizavam as coletividades e possibilitavam sua convivência pacífica. A vida cotidiana, ainda que não permeada pelos rigores dos "rituais da ordem", estava atrelada à vida oficial. Apesar da necessidade daqueles elementos coercitivos para a vida em sociedade, eles eram percebidos como instâncias negativas, no sentido de que constrangiam a verdadeira natureza humana, impossibilitando a realização das qualidades intrínsecas à humanidade, como a igualdade, a alegria, o descompromisso, o uso desregrado do corpo etc. Dessa perspectiva, Bakhtin estabelece uma conexão com o pensamento de Rousseau, para quem o ser humano é impregnado de bondade natural inescapavelmente cerceada pela vivência coletiva. Ao se juntarem em grupamentos os indivíduos seriam necessariamente confrontados por situações em que a inveja, a disputa, a soberba passariam a constituir ingredientes inerentes à vida em sociedade, sobrepondo-se à bondade natural. A opção pela con- 
vivência social significava, portanto, a deflagração de comportamentos negativos que se impunham aos indivíduos, como o grande pensador atestou em sua própria vida.

De acordo com Bakhtin, a sociedade, no sentido mais formal implicava a associação com o Estado e a Igreja, que descaracterizavam a naturalidade do ser humano, impondo aos indivíduos normas, hierarquias e divisões que violentavam seu descompromisso original, sua alegria, sua liberdade. Atestam esse quadro exatamente os rituais oficiais e religiosos nos quais imperam a ordem, a hierarquia, a rigidez temporal e espacial, a contenção de gestos e de expressões corporais, a marginalização do riso e da alegria, a ocultação do corpo. Bakhtin considera essa vida oficial uma "não vida", uma negação da intrínseca naturalidade humana que afasta o indivíduo de sua essência descompromissada, submetendo-o a constrangimentos perpetrados pela rigidez do Estado e da Igreja. Os escritos do historiador russo foram tão marcantes para o estudo dos aspectos populares das sociedades, que ele adquiriu uma espécie de imunidade contra eventuais críticas a suas reflexões. Fato é que na realidade não existe vida oficial em contraposição à não oficial, no sentido de que as características de uma estejam completamente ausentes da outra. A hierarquia, a separação de classes e a desigualdade social entre os indivíduos estão sempre presentes apesar de que, em alguns momentos, a ordem, a lei, os constrangimentos se apresentem de maneira mais evidente. Em outros, eles aparecem de forma mais flexível, como acontecia no período carnavalesco dos tempos medievais e acontece também nos tempos modernos.

Em termos antropológicos, a estrutura de uma sociedade está sempre presente, em qualquer momento em que tal sociedade seja considerada. A rigidez dos rituais formais, bem como as "desordens" de manifestações como as carnavalescas, acontece tendo como pano de fundo a mesma estrutura social. A estrutura muda lentamente com as modificações culturais que acontecem ao longo da história, mas em dado momento ela conforma - num nível elevado de abstração - quaisquer manifestações, comportamentos e valores engendrados pela sociedade de que ela é a mola mestra. O senso comum pode referir-se aos rituais da ordem como "mais estruturados" em face de comportamentos formais dos indivíduos que dele participam, enquanto os rituais populares, como os carnavalescos, como "desestruturados" ou "não organizados" devido à aparente desorganização que permeia o evento e à informalidade, ao descompromisso, à liberdade e à alegria que impregna seus participantes. O senso comum, entretanto, só percebe a realidade concreta diretamente observada, o que o leva a caracterizar aqueles rituais como diferentes em tudo. Um olhar mais aprofundado sobre aquelas manifestações, como o que deve ser praticado por sociólogos e antropólogos, revela, no entanto, que, apesar das enormes diferenças dos contextos em que ocorrem e do comportamento dos indivíduos, a estrutura da sociedade que as protagoniza é a mesma, e assim continuará até que aconteçam modificações culturais que acabam provocando mudança naquela estrutura.

Alguns rituais expressam mais vigorosamente os elementos da ordem, como os que envolvem os exércitos, os atos públicos relativos ao governo, as celebrações religiosas e as ocasiões formais que envolvem famílias ou coletividades. Esses rituais, porém, 
não são exclusividade dos indivíduos dos estratos superiores da hierarquia social, embora se possa perceber maior associação entre eles. Da mesma maneira, momentos de brincadeira, de descontração, de alegria, de informalidade e de prevalência do riso e da liberdade corporal não constituem monopólio das camadas populares, ainda que elas os possam vivenciar de maneira mais frequente, mantendo com eles laços identitários. Bakhtin radicaliza a separação entre vida oficial e vida não oficial, a ponto de dificultar a percepção de interação entre elas. Considera a primeira de maneira negativa, ao percebê-la constrangedora da liberdade natural do ser humano e idealiza a segunda por libertar os indivíduos que a vivenciam das limitações impostas pelo Estado. Segundo o historiador, momento mágico da vida não oficial era a festa carnavalesca,

em que todos eram iguais e onde reinava uma forma especial de contato livre e familiar entre indivíduos normalmente separados na vida cotidiana pelas barreiras intransponíveis da sua condição, sua fortuna, seu emprego, idade e situação familiar (...) Em consequência, essa eliminação provisória, ao mesmo tempo ideal e efetiva, das relações hierárquicas entre os indivíduos, criava na praça pública um tipo particular de comunicação, inconcebível em situações normais. Elaboravam-se formas especiais do vocabulário e do gesto da praça pública, francas e sem restrições, que aboliam toda a distância entre os indivíduos, liberados das normas correntes da etiqueta e da decência (BAKHTIN, 1996, p. 9; grifos nossos).

Bakhtin, portanto, procura mostrar que as classes populares, libertando-se da dominação do Estado e do poder dos estratos superiores da população, expressavam nos festejos carnavalescos - que também empolgavam indivíduos desses estratos - as qualidades essenciais da humanidade. Embora envolvendo todas as classes, o carnaval, com seu desregramento característico, se associava, por isso mesmo, às classes populares, menos afeitas a rituais que celebravam a ordem. Naquelas festividades, em oposição às festas oficiais, havia inversão de valores, uma vez que a hierarquia era desconsiderada, o respeito formalizado era esquecido, e as regras eram provisoriamente colocadas de lado. Emergia, portanto, o império da igualdade, da fuga temporária da vida comum, da vida oficial.

O historiador russo conseguiu captar um sentimento coletivo autêntico, e suas considerações se aplicam virtualmente a qualquer sociedade dividida em classes, estamentos e grupos dispostos hierarquicamente que, em algum momento, celebram um "ritual de integração", em que os indivíduos se sentem participantes de uma mesma coletividade, irmanada inconscientemente pelo sentimento de pertencimento ao grupamento humano e reconhecendo essa condição igualitária. No entanto, no nível concreto da participação social, não há como apagar as distinções que a cultura tão zelosamente estabelece e com as quais impregna os indivíduos de todas as categorias e de todas as sociedades. Dessa perspectiva, Bakhtin promovia uma visão idealizada das festas carnavalescas e, por extensão, das camadas populares que a protagonizavam. Assim, por um lado, ele descortinou a expressão de um sentimento igualitário entre indivíduos e grupos sociais diferenciados, possibilitado pela festa popular, o que desde então marcou profun- 
damente o estudo das culturas populares, de sua oposição a uma cultura oficial e da forma como no período carnavalesco aquelas anulam, temporariamente, a supremacia desta. Por outro lado, pareceu portar-se como um nativo que acredita ser a fantasia imaginada nos ritos e mitos criados por seus antepassados correspondente à vivência concreta da realidade. Referindo-se à Idade Média, é como se a hierarquia pudesse mesmo, ainda que provisoriamente, ser desconsiderada, como se no momento da festa a igualdade social pudesse sobrepujar as separações e oposições entre indivíduos, grupos e classes que impregnam a vida cotidiana, a vida comum, percebida como vida oficial.

Observações como essas são desconsideradas nas apreciações sobre o pensamento bakhtiniano e as festas populares, mesmo porque as delimitações entre esse pensamento, a vivência concreta das festas e a realidade social da vida cotidiana tendem a permanecer um tanto indefinidas, o que confere alguma ambiguidade a considerações generalizadas, levando a uma conjunção da interpretação do fato com o próprio fato, o que tende a relevar aspectos cruciais da relação entre a festa, a interpretação e a realidade social. Segundo Augusto Ponzio (2008, p.176; grifo nosso), por exemplo,

Bakhtin vê no carnaval medieval a realização da festa em sentido pleno, da festa como forma primitiva da civilização humana - igual ao trabalho -, da festa como concepção de mundo, como expressão de fins superiores aos da pura subsistência humana, expressão do mundo das ideias. No regime feudal, a festa entendida como festa do povo, como realização momentânea do reino utópico da universalidade, da liberdade, da igualdade e da abundância, é considerada como uma espécie de "segunda vida" do povo, uma vida diferente da vida oficial.

O elevado nível de abstração de considerações como essa ombreia com o da interpretação bakhtiniana que "vê" no carnaval medieval uma festa que provisoriamente inverte as condições da vida cotidiana, da vida oficial, apagando no tempo carnavalesco os marcos estruturais constrangedores e separadores característicos dessa vida comum. Dessa maneira, no nível interpretativo compreendem-se facilmente observações como, "contrariamente à festa oficial, o carnaval era o triunfo de uma espécie de liberação provisória da verdade dominante e da abolição provisória de toda hierarquia, de toda regra e tabu" (PONZIO, 2008,, p. 177; grifo nosso). A utilização da expressão "uma espécie de" age no sentido de relativizar o discurso do historiador que na realidade disse, ainda que com outras palavras, que "o carnaval era o triunfo da liberação provisória", em que os indivíduos "normalmente separados na vida cotidiana" faziam um contato "livre e familiar". Havia, portanto, de fato, uma "segunda vida" cujas características eram opostas à "vida oficial". Isso porque o historiador vê em sua interpretação a fotografia da realidade quando afirma, como observamos, que, no carnaval - "em que todos eram iguais" -, os indivíduos segregados na vida cotidiana por suas diferentes condições sociais mantinham "uma forma especial de contato livre e familiar". Também ratifica seu pensamento, não deixando qualquer dúvida quanto à existência concreta da vida carnavalesca, ao afirmar que durante a festividade 
a alienação desaparecia provisoriamente. O homem tornava a si mesmo e sentia-se um ser humano entre os seus semelhantes. $O$ autêntico humanismo que caracterizava essas relações não era em absoluto fruto da imaginação ou do pensamento abstrato, mas experimentava-se concretamente nesse contato vivo, material e sensível. O ideal utópico e o real baseavam-se provisoriamente na percepção carnavalesca do mundo, única no gênero (BAKHTIN, 1996, p. 9; grifos nossos).

Bakhtin deixa-se, então, levar pela fantasia, idealizando o momento carnavalesco através de uma igualdade impossível entre seres humanos, formados e deformados por uma estrutura social permeada por separações e desigualdades extremadas como a que prevalecia na Idade Média. Não obstante, o historiador percebe bem a fluidez da vida social ao contrapor vida oficial e não oficial, cada qual com manifestações sociais de características extremamente diferentes. Apesar de radicalizar aquela oposição como se as duas vidas se articulassem sobre estruturas sociais completamente diferentes, o que não é o caso, isso não impede que se perceba que em determinado momento ou se vive uma ou se vive outra, ainda que todos os indivíduos possam transitar entre elas. E a grande contribuição de Bakhtin aos estudos sociais foi exatamente registrar a importância das festas, da carnavalização no universo social, fato que ainda acontece em algumas culturas modernas, como é o caso do Brasil e seu carnaval. Além disso, ele aprofundou a interpretação da festa popular relacionando-a com características inatas do ser humano, uma espécie de retorno à natureza, com destaque para os aspectos positivos como a alegria, a informalidade, o descompromisso, a relação interpessoal nos moldes familiares.

Esse afastamento da vida cotidiana para um momento marcado por festas carnavalescas esteve mais presente nas sociedades do passado - pelo menos se se considera o período medieval - do que na época moderna. Isso nos leva a pensar que a vida oficial, a vida ordenada que marca o cotidiano da atualidade, tende a abarcar, a submeter, a constranger não só os indivíduos de todas as classes, mas também as manifestações que simbolizam seu inverso, ou seja, o desprendimento da lei, a desordem, a ausência de hierarquia e normas, a igualdade social de todos os participantes da festa.

Em outras palavras, nos últimos séculos, as sociedades e as folias "desregradas" mudaram significativamente com reflexos manifestos nas festas que eram percebidas como "rituais de rebelião", como o carnaval era também considerado. A democratização globalizante que acontece já há muito tempo, a pressão internacional contra regimes autoritários, a visão mais bem difundida de que a igualdade deve ser a bússola a orientar as diferentes sociedades parecem relativizar a "necessidade" de manifestações carnavalescas radicais como as que aconteciam na Idade Média. Talvez seja essa a razão por que o carnaval e outras festas semelhantes estejam sendo praticadas em reduzido número de sociedades modernas. Mesmo com as desigualdades enormes que se observam em vários países - o Brasil entre eles - as classes populares não são tão oprimidas como antigamente e possuem o direito de realizar qualquer manifestação em qualquer período do ano e por qualquer razão. 
Não obstante, está acontecendo entre nós forte enquadramento da vida não oficial dentro de parâmetros mais aceitáveis para a classe popular que almeja esse enquadramento, no sentido de ser plena e oficialmente aceita, reduzindo a necessidade de celebrar uma "revolução simbólica", como acontecia nos dias de carnaval em que a folia era essencialmente marcada pelo sentimento de desafio às regras e inversão dos papéis sociais, antes de as classes populares ocuparem o centro do evento. Felipe Ferreira, em $O$ livro de ouro do carnaval brasileiro, oferece-nos um exemplo desse tipo de ocorrência ao referir-se às modificações ocorridas em nossa festa carnavalesca no início do século passado, quando o Rio de Janeiro constituía o centro de divulgação do "modelo carnavalesco para as outras cidades brasileiras". Segundo o autor,

A reorganização paulatina do carnaval interessava, inicialmente, à elite, visto que, para ela, essa era uma forma de manter-se no comando das ações. Afinal de contas, quem determinava o que seria ou não incluído no Pequeno [das classes populares] ou no Grande [da elite] Carnaval eram, em última instância, elementos da própria elite cultural através principalmente dos jornais. Ao povo interessava a possibilidade de ver seus grupos cada vez mais reconhecidos e recompensados pelas principais instâncias carnavalescas, através da divulgação na imprensa, da possibilidade de se apresentar no mesmo espaço urbano do Grande Carnaval, das participações em concursos, das premiações e, mais tarde, do reconhecimento e da ajuda financeira oficiais (Ferreira, 2004, p. 229).

A recente história do desfile das escolas de samba do Rio de Janeiro tem-se enquadrado nesse processo de domesticação da vida não oficial uma vez que não parecem mais instigar nos participantes da festividade carnavalesca e nos que a ela assistem comportamentos que enfatizam a rebelião contra a ordem estabelecida, como acontecia antes. Isto porque devido a alguns fatores surgidos nas últimas décadas as escolas de samba sofreram enorme transformação que as levou, gradativamente, a se afastar das modalidades carnavalescas bakhtinianas e se aproximar dos tipos de performance mais articuladas com a vida oficial. Embora o sentimento dos participantes possa ainda permanecer vinculado ao processo de carnavalização tradicional, na prática as escolas se conformam cada vez mais a um padrão comportado, formalizado, homogêneo e previsto, como convém a um espetáculo midiático que objetiva empolgar as mais diferentes plateias do país e de várias nações do mundo.

Além disso, envolvidas por uma rede de interesses que vão ao encontro de suas necessidades e perspectivas de ganho e sucesso, as escolas têm passado por um processo que as distancia da postura diletante que anteriormente as impregnava. Como observa Nilton Santos (2009, p. 71), "a profissionalização das escolas de samba, entendida como business que envolve a venda dos direitos de transmissão para as televisões, de fantasias e discos, vagas na rede hoteleira etc., realçada pela relevância do carnavalesco, seria a nosso juízo uma tendência que se consolida". Essa formalização progressiva de uma manifestação popular que originalmente - isto é, antes de adentrarem no desfile oficial, quando já se ajustaram a algum tipo de formalização - se pautava pelo improviso, 
pela informalidade e pela liberdade de movimentos, tende a acontecer com qualquer atividade que passe a ser valorizada e exaltada pela sociedade.

O jogo de vôlei de praia pode ser um exemplo desse tipo. Inicialmente adotado como prática informal, aumentando as opções de lazer na praia, gradativamente foi sendo mais apreciado, valorizado socialmente, de modo a ser incluído em disputas oficiais e campeonatos mundiais. Pode-se mesmo imaginar que o próprio futebol, provavelmente o esporte mais globalizado que existe, tenha começado de maneira muito informal, reunindo alguns amigos para brincar com a bola e, depois, colocando grupos em disputa para atingir o objetivo de fazer mais gols no adversário. Mais recentemente, o surf, praticado informalmente por jovens adeptos de esportes aquáticos em que destreza e coragem se combinam, de atividade "desregrada" passou a ser prática "domesticada", no sentido de ter sido submetida a organizações esportivas que a enquadraram em normas e leis que propiciaram sua gradativa globalização. Atualmente, praticado em vários países do mundo com campeonatos mundiais e inserido na mídia internacional, o surf adquiriu status elevado, uma vez que tende a atrair jovens das classes superiores por implicar considerável disponibilidade econômica. Dessa perspectiva, percebe-se que o sistema social acolhe a demanda dos indivíduos, submetendo a suas regras aquilo que eles querem que faça parte dele, no sentido de ser aprovado oficialmente e passar a desfrutar do prestígio e das benesses que o sistema oferece, como - no caso do futebol - permitir, e mesmo estimular, que as escolas para jovens disponibilizem a prática desse esporte, organizar campeonatos regionais, internacionais etc.

Retornando às escolas de samba, sabe-se que há muito tempo - mais precisamente desde 1930 - elas se tornaram o centro da festa oficial do carnaval e, por isso mesmo, suas apresentações não mais permitiam um comportamento bastante informal e descompromissado como acontecia antes, ainda que seus integrantes pudessem vivenciar um sentimento de subversão da ordem, de alegria, de efusividade e extravasamento. No dizer de Erving Goffman (1974, p. 249-250), esse é um "sentimento de evasão", que ocorre em ocasiões especiais, ou seja, em "atividades que dão algo que permita ao indivíduo esquecer-se de si mesmo, que temporariamente apagam todo sentido que tenha do ambiente no qual e para o qual deve viver". Atraindo cada vez mais a atenção do Estado e dos apreciadores do carnaval, o tamanho das escolas de samba aumentou, e elas passaram a desfrutar de enorme disponibilidade financeira para se equipar e construir belos e enormes carros alegóricos e, particularmente no Rio de Janeiro, se foram sobrepondo a outras manifestações, que praticamente desapareceram, como os bailes de carnaval e as brincadeiras coletivas nas ruas. Nas décadas mais recentes, a partir dos anos 70, esse processo se acelerou, e as escolas de samba acabaram definitivamente submetendo-se aos maiores rigores da ordem, da disciplina, da homogeneidade, ou seja, de tudo aquilo que caracteriza um espetáculo de grandes proporções a ser apreciado em escala nacional e mesmo mundial.

O preço dessa domesticação das escolas de samba foi o afastamento do espírito de carnavalização e da desordem que ele implicava, quando os grupos que se torna- 
ram escolas saíam pelas ruas em completa informalidade, antes de se submeter à ordem - por menos rigorosa que fosse - do desfile oficial. Em outras palavras, esse deslocamento do desfile das agremiações da periferia social para o centro da vida oficial da sociedade teve como resultado a relativização do espírito de carnavalização bakhtiniana.

Esse movimento de incorporação da escola de samba pela estrutura oficial não foi, como era de prever, celebrado por todos os participantes dos desfiles. "Não se pode dizer que as escolas de samba fossem fenômenos puros", observa Hermano Vianna (2007, p.123), "mas se criou em torno delas um aparato que defende essa pureza, condenando toda modificação introduzida no samba". Grupos tradicionais sempre criticaram e se opuseram à modernização das agremiações; não conseguiram, no entanto, deter o rolo compressor que transformou as escolas e seus desfiles em um espetáculo de grandes proporções que não só continua maravilhando o Brasil, mas também tem navegado em águas globais e causado impacto em todos os continentes. Sobre esse tema, de acordo com Fábio Pavão (2010, p. 122), "no Japão, por exemplo, o chamado carnaval de Asakusa mobiliza japoneses nativos que sambam, tocam e cantam músicas que misturam a língua nativa e o português, constituindo hoje o maior desfile de escola de samba fora do Brasil". Apesar das possíveis reclamações quanto à rigidez de comportamento que agora se exige nos desfiles, os componentes das escolas se sentem prestigiados por se vir indiscutivelmente colocados, com suas escolas de samba, no centro da festa carnavalesca.

Esse processo de domesticação das escolas de samba é bem exemplificado por Maria Isaura Pereira de Queiroz (1992, p. 116; grifos nossos) em O carnaval brasileiro: 0 vivido e o mito ao observar que

[na sociedade atual], cada escola é imagem na racionalidade de sua organização; desta sociedade, as escolas celebram a ordem, cuja caução invocam. Pois a ordem é o elemento fundamental para a realização dos folguedos carnavalescos; a obediência estrita à ordem é indispensável para que uma escola seja a grande triunfadora na competição do Reinado de Momo. A voz possante e fortemente ritmada da bateria durante o desfile, despertando em atores e espectadores as mesmas emoções, impondo a todos os mesmos comportamentos, os mesmos gestos, a mesma cadência, não exprime justamente a necessidade primordial de se submeter ao comando que emana da autoridade da escola - ou, simbolicamente, de qualquer autoridade?"

A conclusão de Queiroz sobre o desfile das escolas de samba se coaduna cabalmente com nossas considerações acerca do enquadramento das agremiações pelo ordenamento da "vida oficial", ordem que nesse momento não está invisível, ao contrário do que acontece com os procedimentos e comportamentos "naturais" que praticamos na cotidianidade, sem nos dar conta do aparato repressivo que absorvemos desde o processo de socialização e que nos "comanda" inconscientemente. Aquela ordem transparece claramente durante o desfile, cuja estrutura faz com que as escolas possam até ser percebidas, por olhar atento, como deve ser o dos pesquisadores, como grupamentos de 
exércitos apresentando-se em formais ritos do Estado, ao se submeter ao "comando que emana (...), simbolicamente, de qualquer autoridade".

Também mostra a impossibilidade de alguma experiência social em um "vazio estrutural", de um contexto sem controle, sem organização, sem governo, mesmo porque "as escolas celebram a ordem". Ordem que, por sinal, a par das qualidades intrínsecas à natureza humana destacadas por Bakhtin para fundamentar sua ideia da carnavalização da Idade Média - alegria, igualdade, descompromisso, liberdade do uso do corpo etc. -, mostra a outra face da moeda ao ser descrita por Queiroz como "o elemento fundamental para a realização dos folguedos carnavalescos". Sua argumentação a aproxima dos filósofos contratualistas, como Hobbes, Locke e Rousseau, segundo os quais a sociedade precisa de leis e ordem para se concretizar, porque o ser humano tem "a necessidade primordial de se submeter ao comando que emanada da autoridade". Tem também a necessidade de vivenciar - e de forma alegre - as qualidades que Bakhtin enalteceu na festa carnavalesca. Isso vale para qualquer período da história da humanidade, como também para qualquer situação de qualquer sociedade, mesmo considerando os mais primitivos humanos

Neste ponto defrontamo-nos com um aparente paradoxo. A apresentação das escolas de samba nos moldes atuais não permite exagerada liberdade dos participantes. Independentemente do fato de considerarmos a concepção bakhtiniana do carnaval uma "realidade imaginada" - porque as desigualdades sociais não são realmente superadas pelas manifestações carnavalescas -, o sentimento que prevalece nos desfiles continua sendo esse, como acontecia também com as escolas originais, que sofriam menos constrangimentos e menos controle em suas exibições. Pois, apesar das modificações que "engessaram" os desfiles da atualidade, os componentes continuam manifestando sentimento de liberdade e de igualdade, como se a ilusão carnavalesca subvertesse de fato a ordem social, ainda que provisoriamente. Esse é um sentimento verdadeiro, ainda que na prática, ou seja, um pouco além da cortina de fumaça carnavalesca, a estrutura da vida oficial esteja sempre presente, como pretendemos ter demonstrado em nosso trabalho Escola de samba, ritual e sociedade. Acreditamos que esse sentimento de liberdade, de evasão, a que já nos referimos, esteja presente nas mais inusitadas situações, particularmente aquelas articuladas com manifestações carnavalescas, cuja natureza é inverter - de maneira simbólica, é preciso ressaltar - a estrutura oficial, possibilitando o sentimento verdadeiro dessa inversão.

Exemplo radical dessa vivência simbólica de igualdade entre indivíduos bastante diferenciados seria uma festa carnavalesca realizada em um presídio. Imaginemos que no período de carnaval a administração prisional resolva premiar os funcionários da instituição e os presidiários homens e mulheres com bom comportamento oferecendo-lhes uma festa carnavalesca. Na empolgação carnavalizada - ao som forte e entusiasmante produzido pela bateria de uma escola de samba convidada para o evento - que envolve todos os participantes eles vivenciam um delirante sentimento de liberdade que não experimentavam há muito tempo, acompanhado por sensação de evasão da realidade, de ale- 
gria e de igualdade momentânea. Poder-se-ia, no entanto, dizer que nesse espaço e tempo carnavalescos prisionais haveria redefinição de relacionamentos, esquecimento das hierarquias, igualdade de fato atingindo todos, prisioneiros, policiais, funcionários administrativos, cozinheiros, faxineiros e mesmo o diretor da prisão, se ele estivesse brincando com a esposa ao lado? Pois, guardadas as proporções, esse é o quadro que se observa no carnaval e no desfile das escolas de samba.

Em outras palavras, é "como se" as instâncias estruturais da vida oficial fossem desativadas, possibilitando a vivência simbólica de seu inverso, um mundo sem estrutura, sem constrangimento, sem ordem, sem hierarquia e sem desigualdade. Ou seja, um mundo carnavalescamente perfeito. Como, aliás, Bakhtin vê o carnaval da Idade Média, admitindo que a igualdade entre os indivíduos, na vida imaginada e plenamente sentida, se confundia com a concretude da realidade social. Nesse caso, como admitir um tempo social - ainda que limitado ao período carnavalesco - sem normas, sem diferenciação entre os indivíduos, vivido por agentes que continuam sendo "sociais"? Afinal, mesmo essa "sociabilidade carnavalizada" implica necessariamente a vida em coletividade em que cultura, símbolos e significados, estrutura, normas, valores e padrões de comportamento existem independentemente da vontade, do conhecimento, da imaginação, da consciência e das fantasias dos indivíduos. Como observou Fábio Pavão (2004, p. 94), referindo-se a um componente de escola de samba,

Apesar da "ideologia igualitária" que domina o discurso dos sambistas, verificamos a constituição de um espaço segmentado e hierarquizado, refletindo a estratificação da sociedade abrangente. Cada um sabe perfeitamente o seu lugar no espaço físico. O velho sambista pode olhar para cima e invejar a 'mordomia' do 'camarote vip'. Pode até questionar momentaneamente se a sua exclusão é justa, mas sabe perfeitamente que aquele não é o seu espaço. Mais do que isso, sabe que um grande número de seguranças é arregimentado pela escola para controlar "as fronteiras" que demarcam a divisão espacial, como as 'escadas de acesso'.

Pode-se, portanto, perceber que mesmo numa festa carnavalesca muito animada, há papéis diferenciados que os foliões devem respeitar para o bem da própria festa. Os indivíduos, por exemplo, que tocam algum instrumento ou batem tambores não se confundem com outros carnavalescos, ou seja, não são iguais a eles, não têm status semelhantes aos deles naquele espaço festivo. Em um desfile de escolas de samba a diferenciação entre os componentes é ainda muito mais óbvia. Mestre-sala, porta-bandeira, organizador de alas, puxador de samba-enredo, mestre da bateria, rainha da bateria, componentes da bateria, desfilantes em carros alegóricos, diferentes alas, coordenadores do desfile, tudo isso é muito bem organizado e hierarquizado para que o desempenho da agremiação saia de acordo com o planejado. Cada um daqueles elementos assume um papel específico que demanda, frequentemente, grande envolvimento com a escola, muito treinamento e, às vezes, dedicação que virtualmente transforma os atores em profissionais da arte que apresentam no espetáculo, participando do desfile da "sua" escola de samba por vários anos seguidos. É, por exemplo, o caso de mestre-sala e por- 
ta-bandeira, cujo desempenho implica anos de formação e vínculo especial com a escola de samba por conduzir, durante o desfile, seu símbolo maior, a bandeira. Segundo Renata Gonçalves (2010, p. 18-19),

Em meio à multiplicidade de elementos que se apresentam nos desfiles (...) um par, formado por um homem e uma mulher, representa um 'casal enamorado' que carrega o principal símbolo da escola - a bandeira. Mestre-sala e porta-bandeira, trajados com roupas inspiradas no figurino da nobreza europeia, bailam elegantemente ao som acelerado do samba-enredo (...) O casal gira, executa um minueto, faz a corte com 'mesuras e meneios', apresentando um repertório gestual próprio; ativa a participação de quem os assiste, levanta a arquibancada, arranca aplausos e emociona quem os vê.

Neste ponto, podemos inferir sem sombra de dúvida que não há desfile - e a observação serve para qualquer período da história das escolas de samba - em que possa haver ausência de estrutura, seja das agremiações, seja da sociedade, ou igualdade entre os vários indivíduos e grupos que participam da apresentação da escola. Afinal, como poderia uma coletividade apresentar-se ritualmente com ausência de normas, de desigualdades e de hierarquia se, no próprio evento ritualístico que leva a efeito, esses elementos são básicos para a sua estruturação? No entanto, em que pesem as restrições da ordem à escolas de samba e aos indivíduos que participam do desfile, elas não são assim vivenciadas pelos agentes carnavalescos que mergulham na ilusão da festa idealizada - por idealizar nesse momento a vida em sociedade - e se sentem participantes do carnaval da Idade Média. Inconscientemente fantasiam uma realidade sem normas, na qual impera a alegria que empolga, iguala todos e abole status e hierarquias, como uma manifestação de desejos e sentimentos mais primitivos, inerentes à condição humana, como bem destacou Bakhtin. Pois a nova ordem das escolas de samba as afasta do espírito carnavalesco original e se, por um lado, elas cumprem papel oficial, proporcionando espetáculo de dimensões e performance globais, por outro, distanciam-se cada vez mais do papel que desempenhavam em seu desabrochar, isto é, de provedora de espaço em que os indivíduos reviviam carnavalescamente o início dos tempos antes de se subordinar às injunções da vida social. Esse vazio, que há algum tempo foi deixado pelas escolas de samba, tem sido preenchido no Rio de Janeiro pelos blocos carnavalescos que vêm empolgando cada vez mais a população carioca, o que atesta o fato de seu número ter crescido exponencialmente nos últimos tempos.

\section{A HORA E A VEZ DOS BLOCOS}

O crescimento do número de blocos carnavalescos no Rio de Janeiro aponta para o resgate do espírito de carnavalização que as escolas de samba foram perdendo com o enrijecimento de sua estrutura. Essa mudança estrutural foi rápida demais para que o conjunto da sociedade pudesse acompanhar. Uma lenta "descanarvalização" pode ser aceita socialmente, no sentido de que a coletividade se adapta gradativamente à mudança, apesar de ser possível permanecer recalcado no inconsciente coletivo da sociedade um sentimento de perda da "desordem ritual". É o que parece acontecer atualmen- 
te com os países do chamado primeiro mundo que, pelo processo a que já nos referimos de "domesticação" das manifestações populares "desregradas", apresentam apenas festivais ou rituais sintonizados com a "vida oficial". Em outras palavras, as manifestações carnavalizadas acabaram submetendo-se às normas "civilizadas" do Estado, da hierarquia e da formalidade.

Por um lado, os indivíduos desses países não deixam de estar satisfeitos com essa "evolução" que os coloca sob a "ditadura consentida da ordem"; caso contrário, poderiam ter mantido os espaços/tempos reservados a festividades da vida "não oficial" bakhtiniana. Por outro lado, mesmo vivendo apenas a vida oficial, um sentimento de perda da essência da primitividade humana se mantém vivo, a ponto de estimular muitos daqueles indivíduos a recuperar o cenário, o tempo/espaço e a ilusão daquela vida não oficial, praticada pelas sociedades - na visão dos estrangeiros, mas não necessariamente apenas deles - mais primitivas, mais atrasadas, mais alegres e informais, como é o caso do Brasil. Assim, não é por outra razão que enormes grupos de turistas e mesmo celebridades desembarcam em nosso país no período carnavalesco. Eles vêm, inconscientemente, em busca da felicidade perdida, da revivescência da carnavalização bakhtiniana, da alegria desenfreada, dos corpos desnudos, dos sentimentos de plena igualdade que suas sociedades dissolveram sob o manto da civilização ultrarregrada.

Não percebem o que brasileiros, particularmente parte significativa da população carioca, já estão sentindo, e se mobilizando para compensar: a pesada estrutura da "vida oficial" que está sendo reproduzida no carnaval das escolas de samba e no espetáculo global que agora protagonizam. O comportamento dos estrangeiros, porém, continua sendo compartilhado por grande parcela da população brasileira, que ainda vê a festa carnavalesca com olhares e sentimentos medievais, uma vez que acredita e sente que naquele momento a vida informal, a vida não oficial, com tudo aquilo que ela significa, está ali concretamente presente, envolvendo-a com alegria, com um manto de igualdade e com o descompromisso em larga escala a tudo que seja formal e oficial. Portanto, nós, brasileiros primitivos (aos olhos dos estrangeiros, e, às vezes, aos nossos também) mantemos ainda a virtude, por eles plenamente reconhecida, de reconectá-los com a essência da humanidade não mais disponível em seus rituais e festividades, que se afastaram da "forma primitiva da civilização humana".

Esse processo parece assemelhar-se com o que acontece com nossa percepção "bom-selvagista" das sociedades indígenas. Apesar de praticarmos atividades de carnavalização, ainda nos extasiamos com formas "mais primitivas" de ser, como acreditamos que aconteça com os indígenas, em face de sua proximidade com a natureza - que atualmente tanto nos ameaça-, com os animais, com os espíritos e com a verdadeira nudez. Nesse aspecto, é interessante notar que, para os indígenas - e, se considerarmos bem, para muitos de nós -, eles não estão nus como os animais, o que é obviamente comprovado pelas tatuagens e pelos adornos que lhes enfeitam o corpo. Portanto, não estão nus; em uma visão poética pode-se dizer que estão, sim, vestidos de nudez. Nosso olhar sobre os indígenas continua a idealizá-los, a fantasiá-los com a pureza natural rousseau- 
niana que, não podendo ser experimentada por nós, concretizamos nos primitivos contemporâneos pretensamente não alcançados pelos vícios da civilização desregrada, que, essa sim, vivemos plenamente.

Nossa idolatria pelos "nobres selvagens", a bem da verdade, espalha-se também pelos países ditos avançados. Muito provavelmente não terá sido por outra razão que o trabalho de Margaret Mead Coming of age in Samoa (1981; originalmente publicado em 1928), enaltecendo desmesuradamente a figura do "bom selvagem", foi o livro mais vendido na história da antropologia. Na realidade, a pesquisa constituiu a mais deslavada fraude antropológica de que se tem notícia, tendo sido impiedosa e competentemente desmascarada por Derek Freeman $(1984,1999)$. Durante décadas, não só a massa dos extasiados "bom-selvagistas" do primeiro mundo, bem como muitos intelectuais associados à linha posteriormente denominada "determinismo cultural", se deleitou com o olhar crítico às sociedades avançadas depois de comparadas ao nirvana social dos "nobres selvagens" de Samoa. As folias carnavalescas, de algum modo, agem como as idealizações de Margaret Mead sobre a vida tribal, ainda mantidas como reminiscências de um passado que vive dentro de nós e que precisa ser resgatado para nos convencer de que em um passado remoto éramos felizes e podemos continuar a sê-lo, ainda que simbólica e episodicamente no presente.

Eis-nos, portanto, não completamente satisfeitos com nossas regradas carnavalizações, o que nos induz à busca das raízes mais profundas da verdadeira - se é que ela existe - essência humana, cuja caracterização talvez seja digna apenas do homo sapiens. A humanidade, particularmente nos últimos séculos, acelerou o processo civilizatório que tem desembocado em vida oficial marcada pela formalização, qualidade que impregna os mais descompromissados momentos e espaços da vida cotidiana. Pois, embora racionalmente os indivíduos das sociedades mais avançadas se orgulhem do fato de terem atingido elevado patamar de civilização, em que se pode sonhar com algumas ideias que homogeneízam os seres humanos através da igualdade social promovida pelo sistema político, eles não perderam a propensão de desfrutar aspectos do comportamento primevo, sintetizados na vida não oficial do carnaval bakhtiniano. Pois, nesta modernidade, além de vivenciarmos mais de perto o espírito de carnavalização que emana do desfile das escolas de samba, nós, selvagens brasileiros, estimulamos nos indivíduos das sociedades mais avançadas o resgate da primitividade essencial da humanidade que sua cultura não tem mais condições de patrocinar nem simbolicamente.

A retomada de uma mais autêntica festividade carnavalesca está sendo possível, entre nós, pela constituição dos blocos carnavalescos, nos quais se pode viver uma situação consideravelmente "desregrada", sintonizada com a carnavalização bakhtiniana. Como bem lembra Taís Penna de Queiroz (2010, p. 5), "os blocos de carnaval de rua ficaram por muito tempo adormecidos no imaginário da cena carioca, dominada pelas estruturas físicas e midiáticas das escolas de samba. Na última década, o carnaval de rua revigorou-se e voltou com toda a força". Considerando que em 2008 cerca de 400 blocos tomaram conta das ruas do Rio de Janeiro durante o carnaval - um dos quais, conhecido 
como Cordão do Bola Preta, congregou população de aproximadamente 500 mil foliões (Revista O Globo, 8 fev. 2009, p. 20 e 22) -, podemos avaliar o potencial de crescimento desses grupos carnavalescos ao nos dar conta de que, neste ano de 2010, "710 blocos animaram os foliões em todas as regiões da cidade, com cerca de 3,5 milhões de pessoas participando dessa manifestação carnavalesca" (Queiroz, 2010). Como já observamos, os blocos recuperam aspectos da "primitiva carnavalização" da Idade Média, como a alegria, a informalidade, o descompromisso e o uso desregrado do corpo e da linguagem. Durante sua apresentação, as diferenciações sociais, as desigualdades entre os indivíduos e a hierarquia da "vida oficial" não são descartadas, mas a rigidez dessas normas são consideravelmente abrandadas, o que possibilita aos participantes proximidade relacional muito diferente do que acontece na vida cotidiana, quando o respeito aos outros e a formalidade do contato com estranhos se impõem adequada e inescapavelmente.

Uma das características que empolgam os blocos é o desafio a padrões de comportamento e de valores que impregnam a "vida oficial". E o fazem de maneira radical, uma vez que focalizam temas "sacralizados" pela sociedade, com destaque para a sexualidade. Investem, pois, no desregramento do mundo sexual manifestando-se através do uso de palavras, gestos, expressões corporais e as mais variadas fantasias (apresentadas tanto por mulheres, como por homens) que desafiam particularmente o campo feminino - socialmente percebido como o mais contido e mais reprimido com relação ao sexo - através de comportamentos, fantasias e vestimentas sintonizadas com o uso circense do corpo, exibido com muito pouca roupa, e provocam sexualmente os demais participantes do desfile e os que a ele assistem. O campo masculino também é objeto de zombaria e "exposições sexuais" cotidianamente reprimidas, como é o caso dos travestis e daqueles que apresentam características marcadamente homossexuais, através das roupas e gestos afeminados.

Os nomes dos blocos - frequentemente pelo uso de palavras com duplo sentido, ou do jogo de palavras com significado já conhecido - antecipam a provocação sexual carnavalesca estimulando os foliões a entrar "no espírito" do desafio, predispondo-os a usar fantasias e realizar performances adequadas à apresentação. Veja-se, por exemplo, o nome destes blocos, que desfilaram em 2010: Se me der eu como; Assa o pão, mas não queima a rosca; Fogo na cueca; Aperta que eu gosto; Bonde do corno; Calma, calma, sua piranha; Dá um cadinho pra nós; Deita, mas não dorme; É pequeno, mas vai crescer; Fazendários do amor; Imprensa que eu gosto; Me dá teu gancho, que eu mostro meu pivô; Meu amor, eu vou ali; Meu bem, volto já; Nem muda, nem sai de cima; Ninguém é dono de ninguém; Os homens querem casar; Pinto na perereca; Qual seu preço, meu amor?; Regula, mas libera; Rola cansada de Vaz Lobo; Se não guenta, por que veio?; Se não quiser me dar, me empresta; Vem cá, me dá; Vem ni mim que sou facinha; Você não vale nada, mas eu gosto de você (Queiroz, 2010, p. 7-8).

Músicas executadas em alto volume por "grupos de bateria" ou carro de som (com ou sem músicos) com letras que se coadunam com o perfil do bloco constituem elementos essenciais para sua apresentação. Isso porque orquestram a dança, os ginga- 
dos dos corpos dos participantes e a linguagem cantada das músicas, atuando no sentido de "equalizar" homens e mulheres, fragilizando as oposições entre eles e elas, de modo a aproximar os gêneros e possibilitar interação "carnavalizada" entre eles muito diferente de suas performances interativas na "vida oficial" da formalidade cotidiana. Com a liberdade de expressão que os blocos permitem, os indivíduos colocam na cena carnavalesca os personagens com os quais têm, consciente ou inconscientemente, alguma conexão e que representam de maneira jocosa no bloco de que participam. Geralmente são representações idealizadas - como as que se referem aos heróis - ou, então, aquelas que dizem respeito a papéis que se encontram à margem da sociedade, como prostitutas, travestis, homossexuais, mendigos, malandros, presidiários, garis, palhaços e vários outros personagens exóticos que usam roupas extravagantes ou mostram o corpo escassamente coberto com peças que chamam a atenção das pessoas que assistem a sua exibição. Ao som da música alegre, cantada por boa parte dos foliões e do som forte da bateria, os blocos possibilitam aos participantes, e também aos observadores, a experimentação do sentimento de carnavalização que Bakhtin atribuiu aos indivíduos que celebravam a "vida não oficial" na Idade Média.

Não se pode, porém, obviamente, dizer que no carnaval dos blocos haja inversão de papéis entre pessoas das classes superiores e das classes populares nem mesmo que a ordem, a hierarquia e a desigualdade sejam, ainda que temporariamente, suspensas. Não custa lembrar que há uma série de providências burocráticas que os organizadores dos blocos têm que tomar - desde sua inscrição no órgão responsável por essa manifestação carnavalesca na prefeitura até a informação dos locais por onde o bloco deverá se deslocar para evitar a confluência de grupos nos mesmo locais - para que sejam autorizados a "botar o bloco na rua". No entanto, como essas providências são tomadas bem antes do período de carnaval, elas parecem não permear a folia dos blocos que acontece em um tempo/espaço "distante" das injunções formais/administrativas que a oficializam. Realmente, com exceção dos organizadores, que devem estar atentos aos limites da desordem, da informalidade e de eventuais comportamentos desarrazoados, os demais participantes dos blocos, em regra, compartilham sentimento de carnavalização digno da Idade Média. Adequadamente balizados por limites comportamentais que concedem liberdade impensável em dias comuns, os foliões se acham como se estivessem de fato vivendo em um contexto marcado pela "vida não oficial" bakhtiniana.

Em outras palavras, as normas da "vida oficial", embora continuem operando em qualquer momento do período carnavalesco, se encontram extremamente flexibilizadas no contexto de apresentação dos blocos, a ponto de propiciar aos foliões o sentimento de ausência de regras, de igualdade ideal e de alegria desmesurada. Tal sentimento parece refletir a realidade concreta daquele momento, porque cada indivíduo vê no outro alguém que vivencia a mesma realidade uma vez que se comporta com iguais desenvoltura, liberdade e desregramento. Esse compartilhamento da vivência informal e igualitária aproxima realmente os indivíduos, com destaque para homens e mulheres, que mantêm 
contato bem mais próximo e descontraído do que nos dias comuns, permeados pelas formalidades da "vida oficial".

O que se percebe, portanto, é que, tendo-se distanciado do espírito carnavalesco - que consagrou suas origens - devido ao progressivo enrijecimento de sua estrutura, as escolas de samba estão sendo substituídas pelos blocos carnavalescos no que concerne ao papel de restauradores simbólicos das qualidades essenciais da humanidade destacados por Bakhtin, ou seja, a igualdade, a alegria, o despojamento, a improvisação, a criatividade, o uso desregrado da linguagem e do corpo, a ausência da formalidade e da hierarquia. Esse retorno simbólico à primitividade do ser humano não pode ainda ser abolido em nosso país, pois nosso selvagismo real não é suficiente para deixarmos de lado as brincadeiras que revivem o primitivismo radical que humanizava nossos ancestrais, constituindo sua verdadeira essência. Não estamos, portanto, preparados para desconsiderar a prática simbólica desse retorno ao passado, como também acontecia com as sociedades da Idade Média. As escolas de samba podem desempenhar esse papel para os turistas das sociedades mais avançadas, os quais não percebem os exageros da sua formalização que as têm aproximado, cada vez mais, dos rigores da "vida oficial", mas, para nós, que as conhecemos de perto, elas estão deixando de representar o delírio primitivo do carnaval bahktiniano. Resta-nos, pois, apostar nos blocos carnavalescos que, estes sim, nos acenam - no medievalismo moderno em que vivemos - com a potencialidade de nos remeter simbolicamente à primitividade de que ainda não podemos abrir mão e que representam para nós o renascimento da carnavalização original. Primitividade, aliás, que nos ombreia a todos nesta modernidade globalizada, quer sejamos indivíduos do primeiro mundo, de países em desenvolvimento ou verdadeiros indígenas, uma vez que no fundo, ou melhor, somente um pouco abaixo da superfície somos todos iguais: apenas humanos, simplesmente humanos, ridiculamente humanos, selvagemente humanos.

\section{REFERÊNCIAS BIBLIOGRÁFICAS}

BAKHTIN, Mikhail. A cultura popular na Idade Média e no Renascimento: o contexto de François Rabelais. 3a. ed. São Paulo/Brasília: Hucitec/Udunb, 1996.

FERREIRA, Felipe. O livro de ouro do carnaval brasileiro. Rio de Janeiro: Ediouro, 2004.

FREEMAN, Derek. Margaret Mead and Samoa: the making and unmaking of an anthropological myth. Harmondsworth: Penguin, 1984.

. The fateful hoaxing of Margaret Mead: a historical analysis of her Samoan research. Boulder: Westview, 1999.

GOFFMAN, Erving. Manicômio, prisões e conventos. São Paulo: Perspectiva, 1974.

GONÇALVES, Renata de Sá. A dança nobre do carnaval. Rio de Janeiro: Aeroplano, 2010.

MEAD, Margaret. Coming of age in Samoa. Harmondsworth: Penguin, 1981.

PAVÃO, Fábio Oliveira. A dança da identidade: os usos e significados do samba no mundo globalizado. Tese de doutorado apresentada ao Programa de Pós-Graduação em Antropologia da Universidade Federal Fluminense, 2010.

PONZIO, Augusto. A revolução bakhtiniana: o pensamento de Bakhtin e a ideologia contemporânea. São Paulo: Contexto, 2008. 
QUEIROZ, Maria Isaura P. de. Carnaval brasileiro: o vivido e o mito. São Paulo: Brasiliense, 1992.

QUEIROZ, Tais Penna de. A ritualização nos blocos do carnaval carioca. Trabalho de curso apresentada no Programa de Pós-Graduação em Antropologia da Universidade Federal Fluminense, digitalizado, 2010.

SANTOS, Nilton. A arte do efêmero: carnavalescos e mediação cultural no Rio de Janeiro. Rio de Janeiro: Epicuri, 2009.

VIANNA, Hermano. O mistério do samba. 6a. ed. Rio de Janeiro: Zahar/EdUFRJ, 2007.

José Sávio Leopoldi é professor do PPGA em Antropologia da UFF, doutor e pós-doutor em antropologia pela USP e mestre em antropologia pelo Museu Nacional (UFRJ) e pela Universidade de Oxford (Inglaterra).

Artigo recebido em outubro de 2010 e aceito para publicação em outubro 2010. 